\title{
0 êxito da gula: a indestrutibilidade da imagem totem no caso Aylan Kurdi ${ }^{1}$
}

\section{Ana Paula da Rosa}

\section{Resumo}

Em um cenário marcado pela midiatização, a cultura é atravessada por lógicas comunicacionais que se evidenciam nos dispositivos midiáticos. Tal contexto é o pano de fundo deste artigo que visa a discutir a circulação da imagem de Aylan Kurdi, encontrado morto em uma praia em setembro de 2015. A partir da hipótese de cinco movimentos de circulação (ROSA, 2015), questiona-se: em que medida as fagias social e midiática, perceptíveis pelo consumo e replicação de fotografias, permitem mobilizar o programa da gula, criado por Flusser? Para responder a esta questão desenvolvemos a análise empírica do caso, além do tensionamento conceitual de iconofagia (BAITELL0 JR, 2005), de gula (FLUSSER,2006), além dos aportes da midiatização.

\section{Palavras-Chave}

Imagem. Símbolo. Midiatização.
Ana Paula da Rosa I anarosa208@yahoo.com.br Doutora em Ciências da Comunicação pela Universidade do Vale do Rio dos Sinos -UNISINOS, Brasil. Professora e Pesquisadora no Programa de Pós-Graduação em Ciências da Comunicação da UNISINOS.

\section{Introdução}

Cultura e comunicação parecem imbricados visceralmente. Desde o surgimento do homem, a comunicação incide sobre sua cultura, uma vez que os modos de se expressar frente aos outros, consigo mesmo, implicam em relações de comunicação. No entanto, a comunicação de que falamos aqui é esta que envolve 0 corpo, mas que extrapola suas dimensões, expandindo-se a ponto de se manifestar nos meios de comunicação. Se entendemos 0 momento atual como parte de um processo evolutivo de midiatizaçã $0^{2}$, compreendemos que as lógicas midiáticas já não estão mais restritas ao campo dos media ${ }^{3}$, como tínhamos na sociedade dos meios. A partir do século XX, os processos sócio-técnicos foram ampliando os acessos e fazendo com que 0 conhecimento, antes restrito, passasse a pertencer à cultura de todos e de cada um. Cada vez mais é comum que as lógicas midiáticas sejam dominadas e se transformem em práticas e usos, permitindo apropriações em níveis diferenciados de conhecimento 
conforme as possibilidades de acesso às tecnologias e dispositivos ${ }^{4}$.

Ante o exposto, partimos, neste texto, de um cenário marcado pela midiatização em processo crescente $^{5}$, portanto não finalizado. De outro lado, temos a cultura que, para ser explicada, precisa levar em conta diversos parâmetros, dentre os quais a própria comunicação, pois esta afeta, em especial, as imagens. Se o mundo se revela em crise, em função de processos sócio-políticos e históricos, as imagens aguçam e convocam estruturas simbólicas ${ }^{6}$, acionando memórias. Quando publicadas nos meios de comunicação e inseridas no processo de circulação, a partir das reelaborações dos atores sociais midiatizados, tais imagens ganham vida própria, autonomizam-se. Os homens passam a devorar imagens, nem sempre as digerindo, mas inevitavelmente expelindo-as no processo circulatório. Este artigo visa a discutir a circulação das imagens do menino sírio Aylan Kurdi, encontrado morto em uma praia, na Turquia. A imagem se tornou a mais vista em todo o mundo, conquistando o primeiro lugar nos Trending Topics do Twitter em poucos minutos, e constituindo-se no símbolo ${ }^{7}$ da crise da imigração Síria. A partir da hipótese de cinco movimentos de circulação da imagem na midiatização (ROSA, 2015), questiona-se em que medida as "fagias" social e midiática, perceptíveis pelo consumo e replicação de fotografias, permitem mobilizar o programa da gula, criado por Flusser? Para tentarmos responder

Versão revisada de artigo apresentado no GT Comunicação e Cultura do $25^{\circ}$ Congresso Nacional da Compós (Associação Nacional de Programas de Pós-Graduação em Comunicação), realizado de 07 a 10 de junho de 2016, no campus da UFGF, em Goiânia.

Verón (2014).

3 Campo dos media é uma expressão muito utilizada na perspectiva da midiatização para designar o campo social constituído pelas instituições midiáticas e suas regras. Adriano Duarte Rodrigues (2000) considera que a experiência moderna resulta em uma autonomização dos dispositivos e "da instituição de um campo dotado de legitimidade para superintender à experiência de mediação", isto é, o campo dos media. Este campo faz emergir aspectos fronteiriços entre os outros campos, sendo responsável pelo controle social ou pela tentativa de obtê-lo.

Neste trabalho diferenciamos tecnologias de dispositivos, embora o segundo contenha um aspecto tecnológico. A tecnologia dá conta dos avanços da informática, dos aparatos e, consequentemente, dos programas técnicos que permitem as apropriações. Já os dispositivos se configuram por três aspectos: características sócio, semio e técnicas. Ou seja, um dispositivo não é apenas um meio, mas o espaço onde ocorre a articulação entre relações sociais, de linguagem e tecnologia materializados (Ferreira, 2006).

Braga (2012) chama de sociedade em vias de midiatização.

Estruturas simbólicas é um termo proveniente dos estudos de Ernst Cassirer (2004) e também de Gilbert Durand (2004). Refere-se às estruturas profundas do social, símbolos e valores funcionais que se consolidam para além dos anos. Cassirer (1994) distingue o símbolo dos sinais: "um sinal faz parte do mundo físico do ser; um símbolo faz parte do mundo humano do significado". Quando falamos de estruturas simbólicas nos referimos a modos de significação do homem que ultrapassam a materialidade e recorrem à figuras consolidadas historicamente, por exemplo.

Neste trabalho, adotamos o conceito de símbolo a partir de Cassirer (1994) que destaca que o símbolo pertence ao mundo dos significados, mas tais significados são apresentados via materialidades, mesmo que não possam ser claramente representados. 
a esta questão iremos mobilizar neste texto, além da análise empírica, os conceitos de iconofagia de Baitello Jr (2005), da própria gula de Flusser (2006), além dos aportes específicos da midiatização com Verón (2013), Fausto Neto (2008), Braga (2012) e Rosa (2015), dentre outros.

\section{Uma imagem impossível de não olhar: a fotografia de efeito hipnótico}

Quarta-feira, dia 02 de setembro de 2015, o corpo de um menino foi localizado em uma praia da Turquia e recolhido por policiais no litoral da cidade de Bodrum. A criança, chamada Aylan Kurdi, de apenas três anos, fez a travessia do Mar Mediterrâneo na companhia dos pais, fugindo da situação política e econômica da Síria ${ }^{8}$. 0 pequeno barco, em que a família estava, naufragou, assim como outras centenas, desde que a chamada crise imigratória rumo à Europa teve início no ano de 2015. Da família Kurdi, apenas o pai sobreviveu. Porém, foi 0 filho caçula que se transformou em imagem, ao ser fotografado por Nilufer Demir, fotógrafa da Agência de Notícias Dogan News ${ }^{9}$. A empresa redistribuiu a imagem às agências conveniadas, como Reuters e Agence France-Presse (AFP), que, por sua vez, disseminaram as fotografias para inúmeros meios de comunicação ao redor do mundo.

A partir do instante em que a imagem do menino foi publicada pela primeira vez na web, houve centenas de replicações. Pode-se dizer, então, que antes mesmo de se saber quem era 0 "personagem" da cena, o choque causado por uma imagem que não se queria ver, parecia ter o poder de fazer a todos vê-la repetidas vezes, incessantemente. De um lado, atores sociais midiatizados em suas páginas de Facebook, Twitter e blogs compartilhando comentários e a própria imagem, manifestando-se ora contra, ora a favor dos movimentos imigratórios e dos pedidos de asilo. De outro, as instituições midiáticas jornalísticas que, rapidamente, procederam ao acolhimento das imagens produzidas na praia e passaram a oferecer uma cobertura jornalística completa, buscando, principalmente, identificar o nome da criança, sua origem e, claro, oferecer outras imagens que pudessem explicar, abrandar ou complementar a primeira. Do ponto de vista deste artigo, pensando na constituição do caso de pesquisa, que vai além da simples descrição do objeto, identificamos acima nosso campo de observação $0^{10}$. Isto é, trata-se da

Dados obtidos a partir da compilação de diversas matérias jornalísticas disponíveis em Veja, Zero Hora, Folha de São Paulo, The Guardian de 03/09/2015.

A Dogan News é uma agência Turca, que mantém relações de conteúdo em inglês, alemão e chinês desde 1999, especializada em vídeos para TV e documentários, além de fotografias.

10 Metodologicamente, o campo de observação se configura como o movimento de aproximação do empírico, a partir do qual são realizados os primeiros recortes. Trata-se de proceder aos argumentos de Peirce (2003) indução, abdução e dedução, mas preferencialmente a abdução, quando se tem uma hipótese exploratória inicial, que não está focada em teorias prévias, mas nasce da observação dos materiais. Aqui estamos procedendo à delimitação desse campo de observação, numa tentativa de recolher os rastros que estas imagens deixaram. 
imagem do menino Aylan Kurdi (Figuras 1, 2 e

3 ) veiculada por atores sociais midiatizados e também por instituições midiáticas, em especial as jornalísticas.

Figura 1: Policial resgata corpo do menino Sírio na praia de Kos

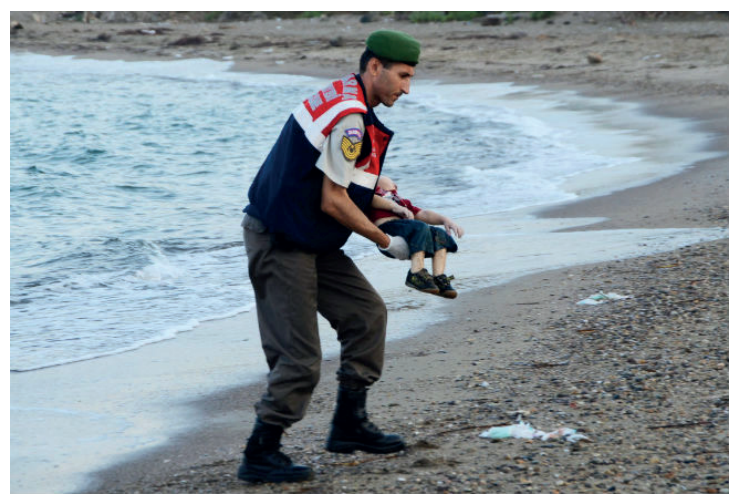

Fonte: Imagem de Nilufer Demir/ Reuters disponível em http:// www.theguardian.com/world/2015/sep/02/shocking-imageof-drowned-syrian-boy-shows-tragic-plight-of-refugees

Figura 2: Imagem que revela o corpo da criança, com rosto submerso

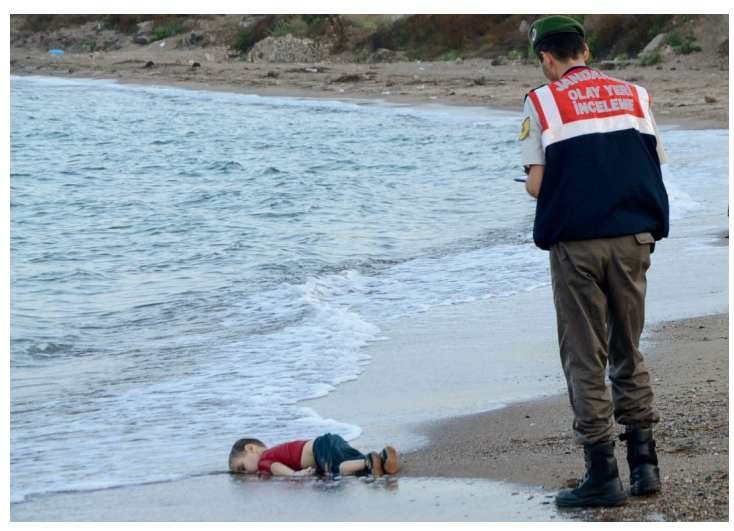

Fonte: Imagem de Nilufer Demir/ Reuters disponível em http:// www.theguardian.com/world/2015/sep/02/shocking-imageof-drowned-syrian-boy-shows-tragic-plight-of-refugees
Figura 3: Imagem de close, opção adotada com mais cautela por veículos jornalísticos

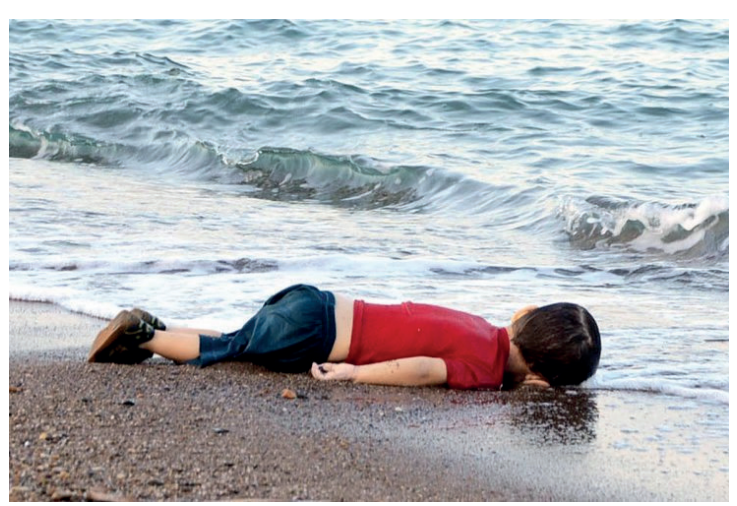

Fonte: Imagem de Nilufer Demir/ Reuters disponível em http://srilankabrief.org/2015/09/at-that-moment-when-isaw-the-3-year-old-aylan-kurdi-i-was-petrified-photographernilufer-demir/

Contudo, verifica-se que há um adensamento do caso. Imediatamente, temos a publicação da imagem, porém, as instituições jornalísticas demandam tempo de apuração e, em função de suas lógicas próprias de produção, possuem tempos diferenciados de distribuição, ainda que tenham disponibilizado conteúdos online tão logo a notícia tenha sido divulgada. A questão é que os tempos de circulação da imagem para atores sociais e instituições jornalísticas são diferenciados, assim como Verón (1980) já ressaltava ao mencionar os gaps entre as gramáticas de produção e de reconhecimento, ainda que tenham se complexificado e hibridizado nos últimos anos. No entanto, como iremos recuperar mais à frente, a construção do sentido com relação às imagens veiculadas, no caso da pesquisa em questão, levam em conta alguns elementos como: a) acessibilidade à imagem; b) trabalho de escolha entre fotografias 
ofertadas com ângulos diferenciados (plano geral com presença do corpo, plano geral sem a exibição plena do corpo e opção pelo close do corpo da criança); c) valorização no processo de inscrição da imagem na circulação; e d) transformação da imagem em símbolo.

Entretanto, o que foi posto em circulação não foi apenas e somente a imagem fotochoque do menino, até porque se trata de uma fotografia com grande apelo de valor-notícia. As replicações subsequentes resultaram em imagens derivadas como ilustrações, charges, vídeos de homenagem, o que significa dizer que, após as produções jornalística e amadora, novos circuitos (BRAGA, 2012) foram produzidos a ponto de a imagem se autonomizar. Surgem como inferências iniciais dois pontos: 1) a imagem feita para a midiatização produz fagias e devorações, retroalimenta uma cadeia, que não digere 0 acontecimento, apenas o reproduz como uma forma de regurgitar; 2) a imagem se transforma em símbolo na circulação, isto é, na atribuição de valor em jogo. Nessa disputa por produção de sentido, elementos profundos do social são acionados, impedindo que novas imagens quebrem as estruturas previamente existentes. Portanto, a imagem traz consigo uma força totêmica. São estas duas possibilidades heurísticas iniciais que iremos refletir, ao longo deste texto, tomando como ponto de partida os movimentos da circulação.

\section{Midiatização e circulação intermidiática: conceitos-chave para a compreensão do observável}

A midiatização é um conceito adotado tanto na Europa quanto na América Latina. Sua presença como fenômeno vem sendo percebida ao longo do tempo, especialmente porque se refere às transformações sociais, culturais e antropológicas derivadas dos fenômenos midiáticos, que se configuram em práticas sociais. Isto é, as lógicas midiáticas afetam todas as esferas, não se restringindo apenas aos profissionais que têm como sua especificidade o fazer midiático, como, por exemplo, instituições jornalísticas. Atualmente estamos imersos em práticas comunicacionais que demandam a compreensão das lógicas midiáticas que, introjetadas no tecido social, passam a ser compartilhadas.

Fausto Neto (2008) explica que a midiatização advém de profundas e complexas transformações sociais, nos seus modos de interação e, claro, na sua articulação com os aparatos tecnológicos, que instauram novos protocolos técnicos.

0corre a disseminação de novos protocolos técnicos em toda extensão da organização social, e de intensificação de processos que vão transformando tecnologias em meios de produção, circulação e recepção de discursos. Já não se trata mais de reconhecer a centralidade dos meios na tarefa de organização de processos interacionais entre os campos sociais, mas de constatar que a constituição e o funcionamento da sociedade - de suas práticas, lógicas e esquemas de codificação - estão 
atravessados e permeados por pressupostos e lógicas do que se denominaria a «cultura da mídia» (FAUSTO NETO, 2008, p. 92)

Essa cultura da mídia permeia as práticas sociais, fazendo com que os atores sociais e as instituições não-midiáticas, para utilizar os termos de Verón (1997), também sejam empoderadas no processo, tendo condições de proceder às interferências múltiplas. Desta forma, há pontos de contatos diversos, ampliando a complexidade da própria comunicação. Neste aspecto, Pedro Gilberto Gomes (2013, p. 136) destaca que a midiatização é uma nova ambiência que impõe uma viragem no modo de ser e de atuar. Tal viragem significa que o sentido social é construído de modo partilhado. Verón (2004) já destacava que esta sociedade emerge porque há mídias que fazem a gestão social, ou seja, que são as intermediárias do processo, uma vez que estas seriam "o lugar (único)" onde se produziriam as representações sociais ${ }^{11}$.

Então, podemos dizer que há um deslocamento: o campo dos media não é mais central, portador de discursos únicos. Os dispositivos midiáticos agora se proliferam, pulverizam, mas o processo de sincronização social permanece ocorrendo por meio daquilo que é posto a circular, uma vez que mesmo tendo uma gama de pluridispositivos à disposição, seja de instituições jornalísticas ou não, percebe-se uma condensação de algumas imagens. Como explicar este processo quando há uma produção cada vez mais acelerada? Para Ferreira (2007), a midiatização envolve três dimensões que se afetam constantemente: processos comunicacionais, contextos sociais e dispositivos, sendo estes últimos um lugar de articulação. Mas o dispositivo não é apenas uma dimensão técnica e tecnológica, ainda que as contenha, trata-se de um lócus no qual o sentido é produzido e partilhado e, por isso, tem um viés dialógico, em que o discurso é expresso, reelaborado. Para que um dispositivo possa se constituir e se estabelecer socialmente ${ }^{12}-\mathrm{e}$, portanto, receber algum tipo de reconhecimento - demanda uso, transformação em prática e possibilidade de reapropriações.

0 dispositivo, quando falamos em imagens, é importante para compreender o processo de inscrição destas e recuperar os engendramentos da circulação. No entanto, é preciso atentar para que a circularidade (inscrições, replicações) não se transforme em sinônimo de circulação midiática. Embora esteja incluída na segunda, a circularidade é apenas parte do processo de circulação. Ao pensarmos que todo sistema produtivo de sentidos conta com produção, circulação e consumo, percebe-se que há

11 Em termos de valor imagem isto é muito forte, pois podemos considerar que o simbólico é reforçado cada vez mais no plano midiático. Ainda que ele seja de uma ordem social, atravesse estruturas profundas da cultura, é nos meios que vemos as trocas, as rememorações e isso incide sobre o modo de perpetuação dos valores- imagem e dos próprios símbolos.

12 Esta formulação sobre o dispositivo enquanto uso, prática, e possível reapropriação está sendo desenvolvida por Ferreira desde 2015 com contribuições desta pesquisadora, principalmente no que diz respeito às reapropriações. 
condições para o funcionamento de cada uma destas instâncias. 0 que nos interessa é exatamente aquilo que está entre a produção e o reconhecimento, entendendo que é possível recuperar os movimentos da circulação a partir das marcas que ficam presentes nas matérias significantes. No caso, buscando refazer os caminhos e acionamentos entre a publicação de suas primeiras imagens até as que foram veiculadas sobre o mesmo tema em 2016, no jornal Charlie Hebdo, e que recuperam a inscrição primeira.

É válido considerar que a circulação, durante muitos anos, foi vista como um desvio entre as gramáticas de produção e de reconhecimento. Porém, o próprio Verón (2013) percebeu que esta zona é mais que um mero espaço entre dois polos, pois é nele que o sentido, de fato, transforma-se. Para Fausto Neto (2013, p.47), na sociedade, em vias de midiatização, a complexidade interacional "se acentua à medida em que a técnica, em de vez produzir ampliação das distâncias entre produtores e receptores, trata de encurtá-las, reunindoas agora na forma de contatos". Acontecem aí acoplamentos de práticas discursivas, o que altera o modo como o sentido é produzido.

A circulação surge, em nossa visada, onde há troca, isto é, refere-se a um processo de atribuição de valor, em que tanto produção como reconhecimento possuem condições de operar sobre o sentido, o que só ocorre quando se reconhece que aquilo que está em jogo - sendo partilhado - é importante, tem valor. No que se refere à imagem, significa dizer que não é apenas a instituição midiática que atribui o que deve ser visto, nem tampouco apenas os atores sociais ou as instituições não-midiáticas, mas que estas três instâncias encontram condições de produzir circuitos nos dispositivos que usam e partilham, construindo novas camadas de sentido sobre aquilo que já foi inicialmente inserido na circulação. Isto porque esta se configura como um processo contínuo, em fluxos incessantes, não-lineares, nutrida por pluridispositivos que permitem acessos, reingressos e devorações, em que os tempos e espaços são naturalmente diferidos e elásticos, principalmente com 0 ambiente digital.

Para Fausto Neto (2013, p.55), a circulação desponta como "um lugar de embates".

Complementamos este ângulo de visão ao afirmar que há uma negociação ou uma disputa visando ao poder de atribuir valor ao que deve ser visto já que, em nosso caso, tratamos de imagens. Tais disputas ocorrem a partir dos dispositivos midiáticos, sendo que, cada vez mais, a produção é feita para a própria circulação, modificando as relações sociais. Tome-se como exemplo a agência da fotografia de Nulifer Demir, especializada em produção de vídeos para redes de televisão e internet, mas que também disponibiliza conteúdo fotográfico. Obviamente este material é produzido para ser ofertado às agências internacionais, não necessariamente com a repercussão deste caso de pesquisa. No entanto, há também atores 
sociais que produzem vídeos e fotografias sobre os imigrantes e que, após o acontecimento, passaram a abastecer, com material imagético, diversos portais e veículos jornalísticos. Isto implica dizer que a construção do sentido social sobre a crise da imigração passa a ser dividida.

Essa construção que se dá no âmbito dos dispositivos pode ocorrer de duas formas: por processos intermidiáticos (entre dispositivos) e/ ou intramidiáticos (no âmago do dispositivo), como ressalta Ferreira (2013). A circulação intermidiática é mais facilmente visualizada na distribuição, o que, em nossa visada, não desmerece seu estudo. A distribuição é importante para a análise da imagem, pois é quando vemos uma fotografia ou um vídeo sendo reinscrito, replicado em dispositivos múltiplos, gerando novas afetações. Ora, trata-se de circulação, pois se refere não simplesmente a como esta imagem aparece em outro lugar, mas como passou por preservações, mutações no sentido, agregações, valorizações.

\section{A circulação intermidiática é marcada pelos} pluridispositivos, isto é, por uma interação que se dá entre vários dispositivos, de diversas ordens, digitais ou não, de instituições midiáticas ou não. Há um circuito de inscrições de imagens, comentários, referências ao tema, enfim, que configuram um fluxo de trocas. Do mesmo modo, na circulação intramidiática se percebe que, no interior do próprio dispositivo ${ }^{13}$, há uma série de inscrições, idas e vindas, de processos circulatórios que se dão apenas no limite das bordas do próprio dispositivo. No entanto, pela observação do caso empírico, percebemos que os dois tipos de circulação se sobrepõem, sendo a intermidiática mais forte, mesmo nos espaços dos atores sociais, 0 que demonstra que o processo de midiatização está mais solidificado.

Assim, podemos dizer que: a) a midiatização se traduz em circulação, ou seja, naquilo que é trocado em fluxos e que se constitui em um valor; b) tais trocas se dão via dispositivos midiáticos que podem ser jornalísticos ou não; c) a circulação ocorre de modo intra e intermidiático, dependendo dos circuitos envolvidos, mas é evidenciada na distribuição dos materiais significantes que podem ser recuperados metodologicamente.

\section{A gula em Flusser $x$ os movimentos de fagia social e fagia midiática}

Ao pensar a circulação intermidiática, definimos movimentos de seu modus operandi em relação à díade atores sociais midiatizados/instituições midiáticas jornalísticas, tendo como base desse raciocínio a compreensão de que a circulação é atribuição de valor. Assim, identificamos cinco movimentos (ROSA, 2015) que podem ser 
denominados como: 1) Tentativa de espelhamento (quando as instituições midiáticas fazem 0 processo de seleção de imagens para afetar atores sociais e instituições não-midiáticas, inserindo-as na circulação); 2) Reflexo (movimento derivado do primeiro, em que os atores sociais replicam as imagens já vistas em seus dispositivos, preservando o sentido original); 3) Fagia Social (movimento de consumo cíclico/reiteração das imagens com novos sentidos sendo agregados, mas preservando a relação com a imagem original); 4) Performático ou celebrização (quando atores sociais midiatizados criam, nos seus dispositivos, novas imagens a partir de lógicas da midiatização) e, por último, 5) Fagia midiática (ocorre quando as instituições midiáticas consomem a imagem produzida pelos atores sociais em seus espaços, integrando-a ao seu discurso, numa espécie de consumo de segundo nível. ${ }^{14}$ Para este texto, só nos interessam os dois tipos de fagia, a social e a midiática, que serão melhor explorados uma vez que dialogam com as noções de iconofagia de Norval Baitello Jr. e de gula de Vilém Flusser.

\section{A fagia social, entendida como movimento da circulação, diz respeito ao uso dos dispositivos midiáticos e não necessariamente de apropriações, ou seja, de criações feitas a partir dele. Significa que a imagem que é inscrita na circulação pela instituição jornalística, como no caso do menino Aylan Kurdi, por exemplo, é}

acolhida pelos atores sociais que passam a inserir esta imagem em seus dispositivos, construindo outros textos sobre ela, comentários, novos títulos, charges, memes. Apesar das novas elaborações, elas preservam a força simbólica original. A imagem é replicada, mas o texto verbal ou a construção da animação sequencial, em vídeo ou slide show, não traduz o mesmo sentido que 0 apresentado pelo jornalismo canônico ipsis literis. Já ocorre um tensionamento, um viés de crítica ou de produção sobre o objeto. Trata-se então do que denominamos de Fagia Social e que tem ligações com a iconofagia de Baitello Jr (2005). Para este autor,

é notável a utilização de imagens precedentes como referência e suporte da memória. Assim, a representação de um objeto não é apenas a representação de algo existente no mundo (concreto, das coisas, ou não concreto, das não-coisas) mas também, uma re-apresentação das maneiras pelas quais este algo já foi apresentado. Em outras palavras, em toda imagem existe uma referência às imagens que a precederam (BAITELLO JR: 2005, p.95).

Assim, estas imagens produzidas pelos atores sociais e reinseridas na circulação, travestidas de novas, são as mesmas imagens anteriores porque mantém uma vinculação profunda de referência. Além disso, a fagia de que se fala aqui está ligada, em analogia, à ação de alimentar-se. Transpondo para o conceito de imagem, principalmente do ponto de vista das imagens exógenas ${ }^{15}$, trata-se de um consumo 
excessivo de imagens, uma fome exacerbada de imagens que são postas em circulação, produzidas para a midiatização e posteriormente reinseridas em dispositivos midiáticos múltiplos, só que pela ordem do social, ou seja, fugindo do controle das instituições midiáticas jornalísticas e adquirindo uma valorização em fluxo. Deste modo, as imagens são devoradas, passam a integrar o imaginário coletivo. Mesmo que haja uma elaboração de outros textos, manchetes, legendas, o olhar continua sendo tragado para as imagens que consideramos como totêmicas, ou seja, que acionam estruturas profundas do social.

Neste caso, tem-se: Atores Sociais Midiatizados (ASM) que inserem imagens jornalísticas em seus dispositivos midiáticos (DM), produzindo novos sentidos sobre elas, reforçando o valor das imagens, não necessariamente dos discursos anteriores. Transpondo para o empírico deste artigo, temos a fagia se apresentando em algumas etapas. Jornalisticamente, temos a inserção quase que unânime da mesma fotografia. Observe-se 0 apanhado de jornais internacionais (figura 4) em que apenas o Independent faz uma opção diferenciada das outras publicações, optando por exibir a crueza da imagem do corpo com mais intensidade. Os demais chegaram, inclusive, a apresentar editoriais em que explicam o porquê de evitar a fotografia em close do menino. Já o The Sun faz uma montagem com duas imagens, mas utiliza a fotografia "padrão".

Figura 4: Compilado de capas de jornais no dia posterior ao acontecimento

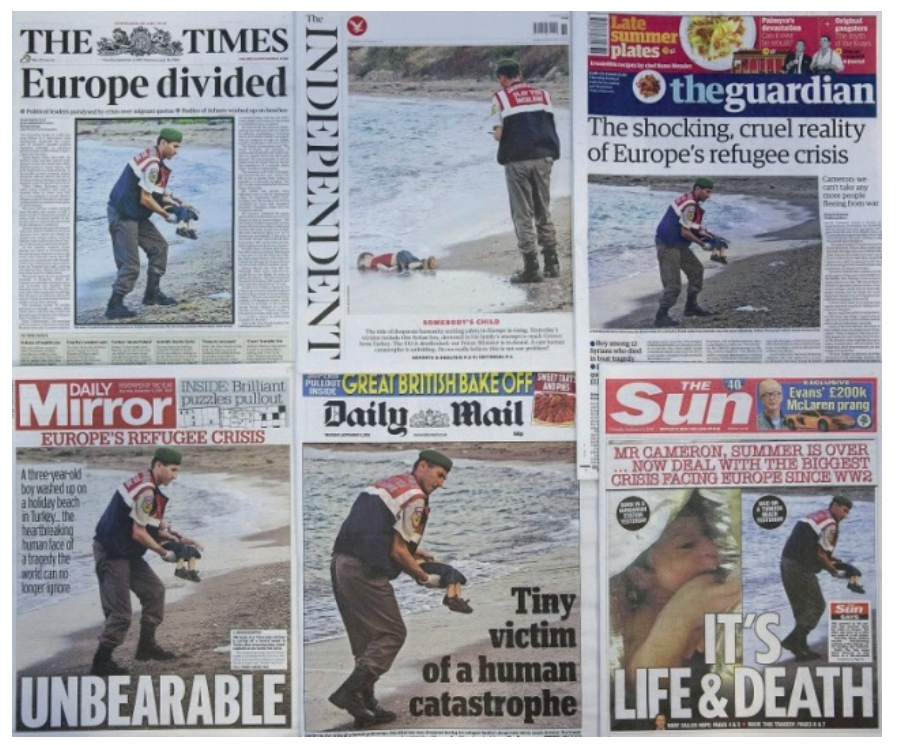

Fonte: http://ewn.co.za/-/media/88AF3C434FAD4500B28035E2684167FF.ashx

15 As imagens exógenas são aquelas exteriores, presentes nos meios de comunicação, em diversos dispositivos diferentes, como diferencia Belting (2004) das endógenas, que são as imagens interiores, pertencentes ao universo do repertório individual de cada um. A cada dia as exógenas se sobrepõem às endógenas, impedindo nossa capacidade imaginativa plena ou a possibilidade de "ver de olhos fechados" como diria Calvino (1998). 
No Brasil, os principais jornais também

escolheram esta imagem como fotografia para estampar suas capas, o que não significa que os outros dois registros feitos por Nulifer Demir não tenham sido veiculadas nas páginas internas, 0 que ocorreu em Zero Hora, Folha de São Paulo e Extra, por exemplo. Mas, como nos referimos ao movimento de fagia social e não da instância midiática, ainda é preciso considerar que os atores sociais fizeram seus comentários e suas postagens especialmente com base na imagem publicada pelo Independent e pela figura 3 deste artigo. Esta imagem foi publicada tanto pela agência de notícias logo após o ocorrido, quanto nas redes sociais, ou seja, mesmo que a produção jornalística do dia seguinte tenha evitado estampar em sua capa a imagem mais "forte" da morte do menino, esta imagem já estava sendo devorada, replicada, uma vez que foi apropriada pelos atores sociais midiatizados em seus dispositivos. Como exemplos desse "tomar para si" temos as páginas de Facebook, os blogs e os vídeos. 0 blog do Evangelista, por exemplo, traz um viés político ao debate, mas reforça as imagens, replicando fotografias publicadas em veículos jornalísticos sem indicar as fontes.

Figura 5: Blog do Evangelista publicado em 8 de setembro de 2015

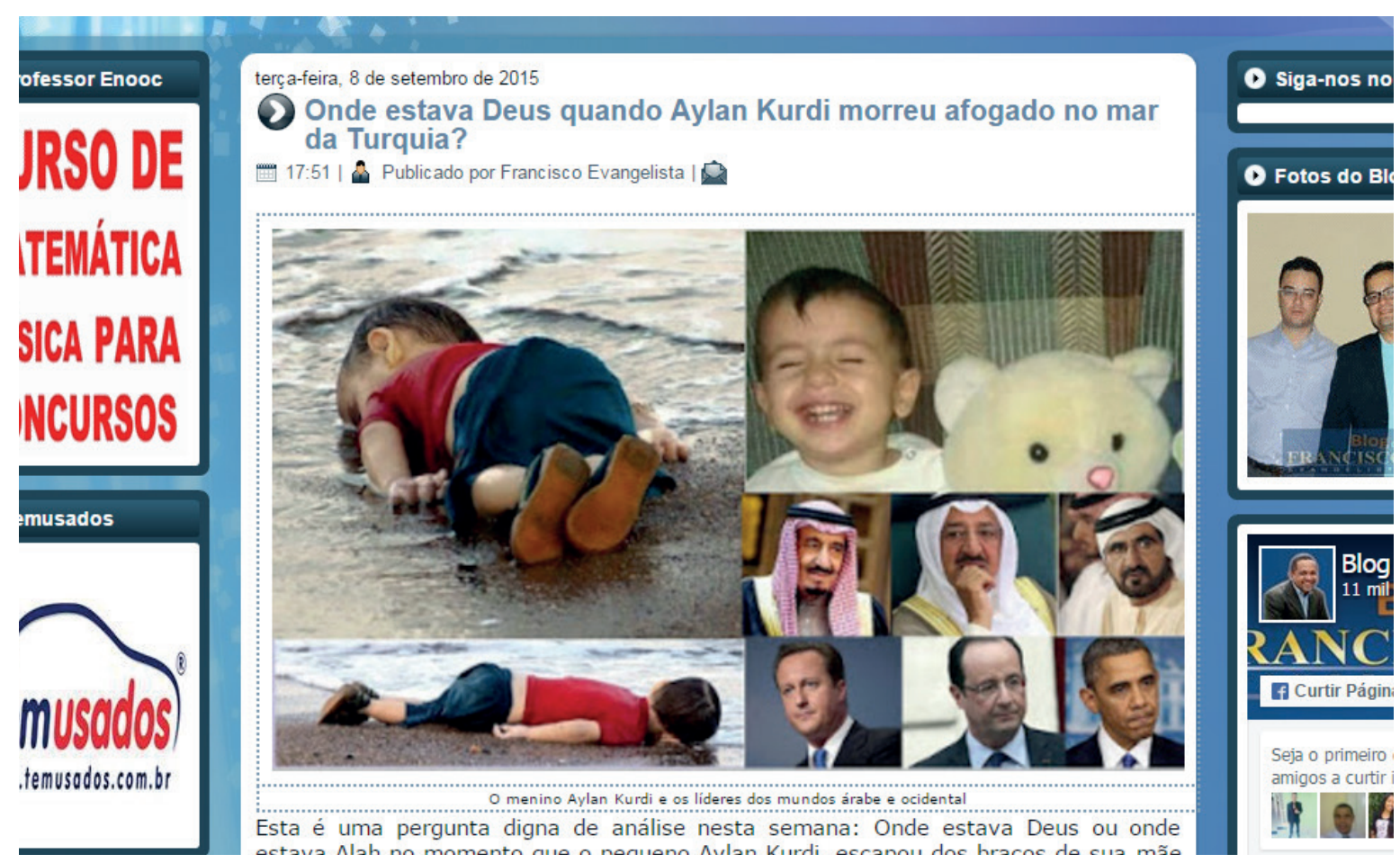

Fonte: http://www.franciscoevangelista.com/2015/09/onde-estava-deus-quando-aylan-kurdi.html 
Figura 6: Imagem e texto recuperado de página do Facebook

\section{Dário Benedito Rodrigues}
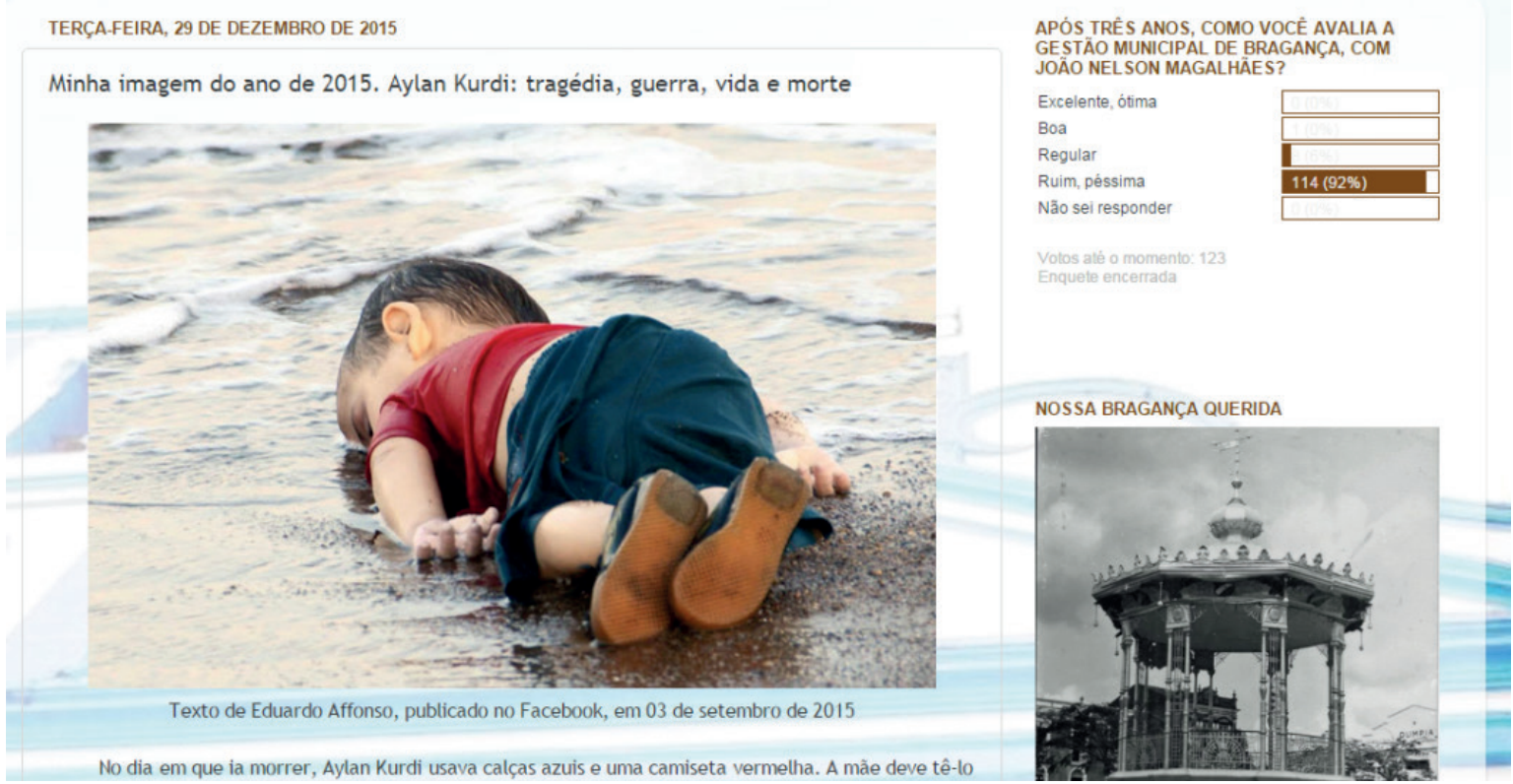

Fonte:http://profdariobenedito.blogspot.com.br/2015/12/minha-imagem-do-ano-de-2015-aylan-kurdi_29.html

Do mesmo modo, Dario Benedito (figura 6)

publica em seu blog, em dezembro de 2015, foto e texto atribuído a outro ator social, em setembro de 2015, constituindo uma devoração da devoração.

Há também a página portuguesa de Facebook criada com o nome de AylanKurdicaravan

(figura 7) num movimento de atores sociais que, a partir da imagem veiculada, conforme relato na própria página, mobilizaram-se para ajudar as vítimas do movimento imigratório na Europa. Tal dispositivo conta com desdobramento em inúmeros países, incluindo o Brasil. Além das doações, o pluridispositivo é marcado pelas fotos de rememoração do menino e por vídeos de homenagens (figura 8) feitas por atores sociais, em que as imagens de Nulifer Demir são inseridas diversas vezes, revalorizadas na circulação.

Figura 7: Página com imagem publicada pela CNN e por jornais de álbum de família

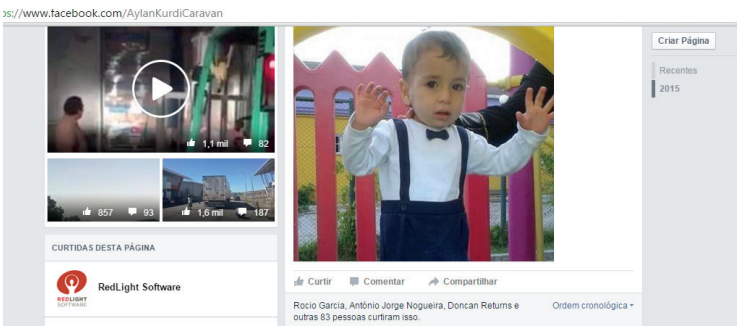

Fonte: www.facebook.com/AylanKurdicaravan 
Figura 8: Vídeo de homenagem em que a letra da música objetifica o menino e humaniza a foto

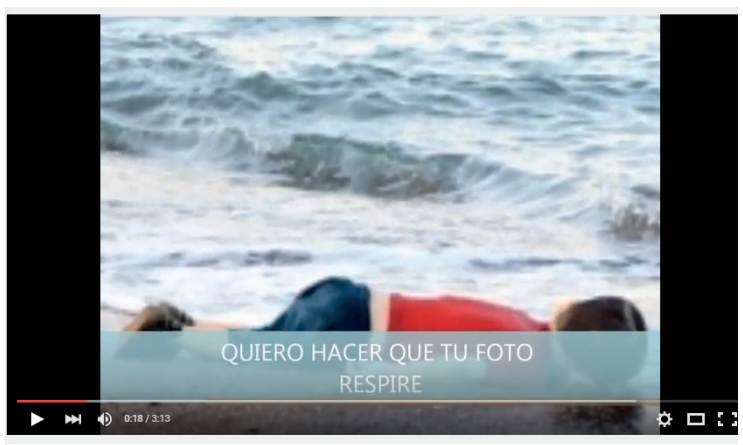

AYLAN KURDI | David Sánchez Guillén

Fonte: https://www.youtube.com/watch?v=SGqs_ vIBKUI\&feature=youtube

Tais imagens remetem ao que Baitello Jr (2005) chama de uma proliferação indiscriminada e compulsiva de imagens exógenas, a ponto de gerar compulsão por apropriação. Ora, se a imagem está disponível, o desejo de consumi-la e de exercer sobre ela algum tipo de produção parece latente e indissociável, ainda mais quando as lógicas midiáticas estão integradas ao cotidiano, instauradas como práticas. A questão é: que tipo de alimentação é essa? Que fome é essa?

Se, de um lado, há um aumento na produção de imagens, de outro, há um número diminuto de imagens que ganham visibilidade, como é o caso destas que pertencem ao corpus deste artigo. Outras crianças e outros imigrantes morreram na travessia da Síria para a Europa, mas algo na imagem de Aylan Kurdi fez com que ele se tornasse este símbolo. Mas o quê? Identificamos algumas possibilidades: $1^{\circ}$ ) 0 fato de que a criança convoca a infância perdida, a inocência,
0 sentimento de proteção familiar; $2^{\circ}$ ) a falência de um sistema político e econômico, que não é o ocidental, e o consequente endeusamento do ocidente como única oportunidade de salvação.

Outra explicação possível para essa fome, também, é o fato de que ela se retroalimenta na instância midiática. Não são apenas os atores sociais que consomem; o jornalismo também consome a própria fome que nutre. 0 fluxo identificado é 0 da instituição midiática jornalística que se apropria de imagem produzida por atores sociais midiatizados a partir de sua inscrição na circulação. É o que denominamos de Fagia Midiática. Este consumo de segundo nível leva a instituição jornalística a produzir um discurso noticioso sobre a elaboração primeira, convocando 0 ator social a fazer parte efetiva da produção jornalística, reforçando que a circulação é um espaço de disputa pelo valor. Nessa situação, os atores sociais possuem condições de também atribuir valor a determinadas imagens para que apareçam ou permaneçam em circulação. Ora, isso não significa, necessariamente, o empoderamento do ator social como sujeito, uma vez que, ao assumir o discurso como seu, o campo jornalístico opera sobre ele a partir de suas lógicas, ritmos, rituais e tempos, muitas vezes adaptando o que é produzido pelo ator social a suas regras e formatações, ainda que lhe dê visibilidade.

A fagia midiática ocorre por quatro motivações:

1) a constatação da ausência ou da falibilidade 
da presença diante dos fatos (é 0 caso de imagens feitas por amadores da chegada de uma embarcação com imigrantes); 2) 0 reconhecimento de uma produção imagética (uma exposição fotográfica, uma página de internet ou vídeo com muita repercussão em que 0 autor se torna notícia); 3) agendamento de softnews (caso de vídeos de amadores que não são surpreendentes pelo conteúdo, mas que ganham notabilidade na própria web); e 4) poder do amador em si, seu capital. Essas motivações são acionadas de modo independente.

Este tipo de fagia implica, portanto, na instituição midiática (IM) que se apropria da fotografia inserida em dispositivos midiáticos (DM) dos atores sociais e reinsere a imagem em dispositivos midiáticos jornalísticos (DMJ), reelaborando-a conforme seu fazer. Tem-se, então, uma circulação a partir da circulação anterior. Como exemplos deste movimento temos, no caso Aylan Kurdi, as postagens feitas por supostos amadores que produziram, a partir das fotografias iniciais, imagens poéticas, comparações com outros períodos históricos e que, no Twitter, usaram a hashtag \# KiyiyaVuranInsanlik para homenagear 0 menino sírio. Tais homenagens foram inseridas em jornais, revistas e em programas de TV, conforme as ilustrações abaixo (figuras 9 e 10), extraídas da edição (online) da Revista Veja e do portal de notícias G1 (figura 11).
Figura 9: Crianças dormindo em cobertor feito pelas ondas do mar

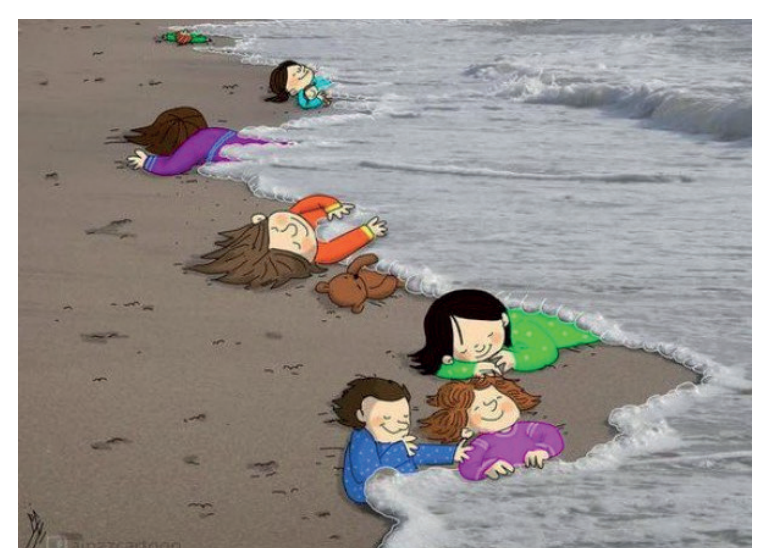

Fonte: http://veja.abril.com.br/noticia/mundo/imagemretrata-grito-de-um-corpo-silencioso-diz-autora-defoto-do-menino-sirio/

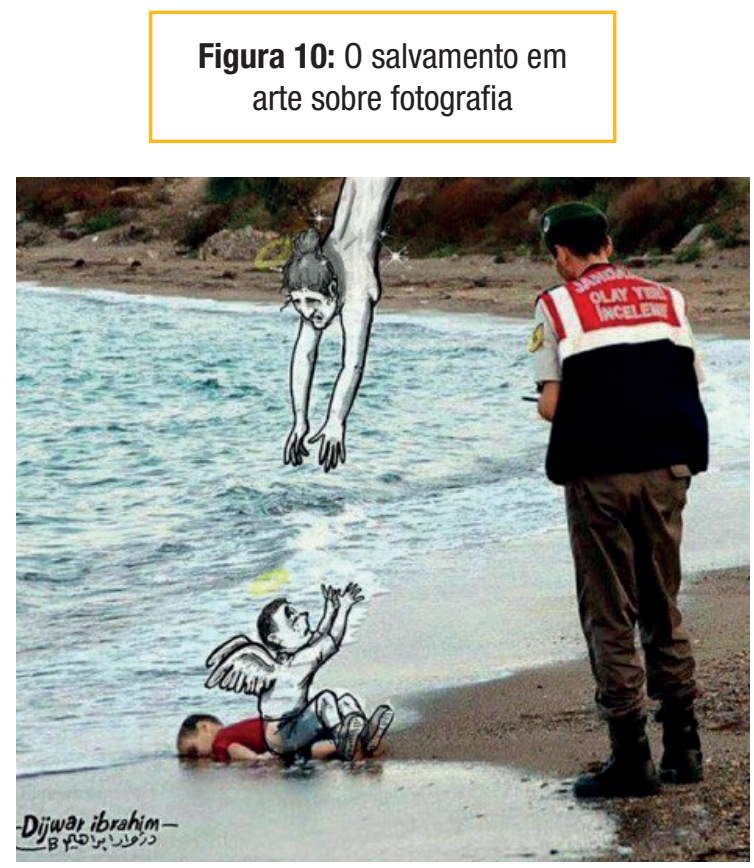

Fonte: http://veja.abril.com.br/noticia/mundo/imagemretrata-grito-de-um-corpo-silencioso-diz-autora-defoto-do-menino-sirio/ 


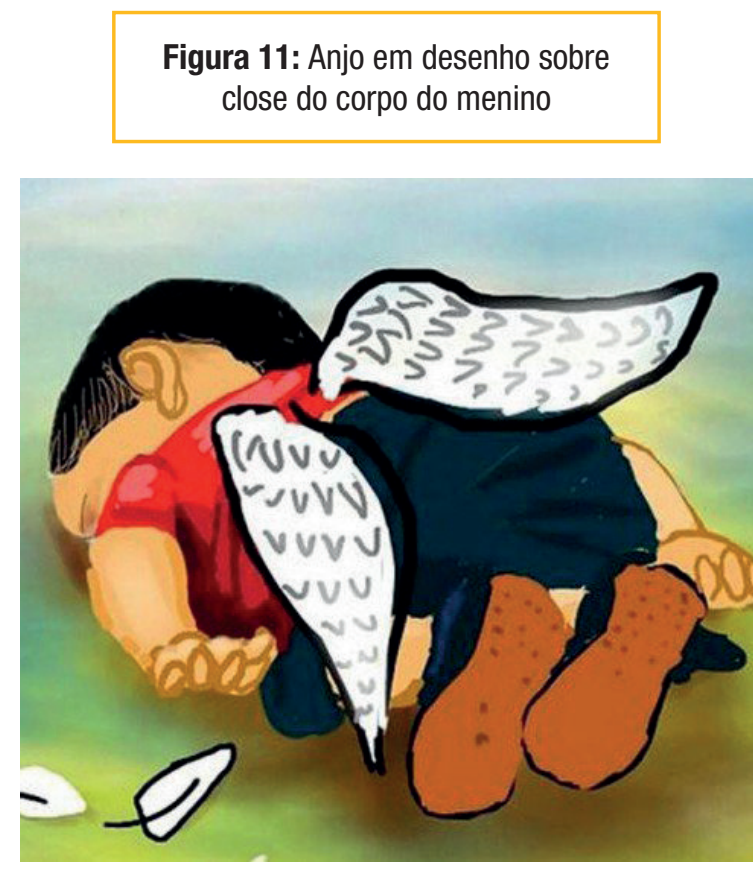

Fonte: http://g1.globo.com/mundo/noticia/2015/09/ ilustracoes-homenageiam-menino-sirio-morto-empraia-em-redes-sociais.html

Fagia social e fagia midiática são facetas da mesma moeda. As instituições midiáticas jornalísticas tanto estimularam o consumo de imagens por parte dos atores sociais midiatizados, popularizando seu modo de fazer, seus instrumentos, que estes atores incorporaram em suas práticas sociais, a fagia de imagens da mídia. Porém, ao mesmo tempo, os atores sociais midiatizados se tornaram produtores para abastecer uma nova fome por eles provocada: a da própria mídia. Assim, temos "imagens à procura de imagens perdidas" que procuram reforçar, tensionar, negociar a fixação das crenças já estabelecidas. 0 visível é construído em jogo, em fluxos, em movimentos de alternância, produção e reconhecimento de valor.

Vilém Flusser (2006), ao tratar da gula, afirmava que "perdemos o senso da realidade, estamos alienados". Assim, para que a vida faça sentido para nós é preciso que ela seja transformada em substância mental, o que implica em ser transformada em real, em algo que nos seja compreensível. Assim, é necessário, conforme 0 autor (2006, p. 121), "devorar, engolir e digerir a vida, para que essa mera virtualidade das nossas mentes se torne em realidade. 0 mundo dos fenômenos não passa de um 'vir-a-ser' da realidade mental que somos". 0 caso do menino sírio precisa ser devorado para ser assimilado, mas ao fazer isso já estamos envoltos nas fases da gula. A gula é semelhante ao metabolismo humano, envolve um estágio inicial (de aprender), um estágio secundário (em que as coisas são de fato engolidas, é 0 aprender englobante). 0 terceiro momento é a digestão (fase da compreensão) e um quarto, marcado pelos detritos (ação transformadora). Comparando estes estágios com os movimentos da fagia social e midiática já mencionados, percebemos claramente a presença da devoração, do engolir, portanto, estágios de aprender. Contudo, no caso Aylan Kurdi não se evidencia a digestão, ou seja, a compreensão dos processos. 0s atores sociais midiatizados estão focados em chancelar novas inscrições na circulação, isto é, em reabastecer o fluxo de materiais significantes, mas isso não implica necessariamente que se trate de compreensão, reflexão aprofundada dos processos. 0 mesmo se pode dizer das instituições midiáticas que reapresentam, reelaboram as imagens já inseridas em outros momentos, mas não obrigatoriamente ampliando o foco para as 
questões cerne do problema a ser enfrentado sócio e culturalmente: é como se ficássemos nas bordas, retidos na fotografia. Muitas imagens são apenas compartilhadas, replicadas em looping, como se tivessem um efeito hipnótico.

No entanto, Flusser ressaltava que a natureza da gula é devorar a natureza para expelir instrumentos, que são mais reais que os objetos da natureza. Neste sentido, as imagens do menino sírio parecem mais reais do que os problemas sociais que nos acometem cotidianamente, sem negar a existência destes. Isto porque a imagem de Aylan se torna autorreferencial, portanto, ela se transforma no próprio acontecimento. Não se trata do corpo boiando na água, nem da crise imigratória, mas da imagem em si. É ela que machuca, é a ela que nos referimos, é ela que consumimos.

Assim, aplicado a este objeto, o programa da gula pode ser sintetizado em: a) devorar o mundo dos sentidos; b) transformar este mundo em um sistema de símbolos e c) criar um número cada vez mais intenso de máquinas e instrumentos que potencializem a força propulsora da própria gula. Quanto mais dispositivos temos à nossa disposição, mais dispositivos tendemos a desejar, inclusive um dentro do outro, ditando nossos ritmos e nossas formas de ver, enquadrar. Podemos até mesmo programar para autodestruição em 24 horas. Isso implica que a gula se traduz em consumo. E esse devorar contínuo acaba resultando em uma das hipóteses aqui postas, a necessidade de regurgitar. A imagem feita para a midiatização produz fagias e devorações, retroalimenta uma cadeia que não digere 0 acontecimento plenamente, apenas o reproduz, inserindo-o novamente no fluxo. Portanto, a circulação é sempre este entre-lugar, essa troca de valores, de devorações anteriores. Novas fagias são suscitadas a ponto de novas imagens serem disponibilizadas, mas é um "novovelho", uma vez que são imagens que carregam consigo as forças das primeiras imagens vistas, chegando a se caracterizar como uma fixação de uma crença, impedindo que outras imagens concorrenciais entrem na circulação.

A imagem-totem, portanto, é aquela que se transforma em uma imagem impossível de ser quebrada ou que, posta à prova, resiste aos fatores tempo, acidez do humor, sendo protegida pelo coletivo, uma vez que é instaurada por ele. Evidencia-se, na processualidade de circulação deste caso, que não há espaço para imagens concorrenciais circularem. As imagens que são inseridas, mesmo que busquem um "outro" olhar, são, na verdade, o mesmo ângulo, a partir do uso de outras tecnologias (o desenho, a ilustração digital, o grafite. 0 Jornal Charlie Hebdo, por duas vezes, foi uma voz dissonante no contexto das instituições midiáticas e, nas duas ocasiões, foi amplamente rechaçado. Isto ocorreu em 2015 e em 2016, o que demonstra que, mesmo passado o período mais intenso de exibições, a imagem está cristalizada. 


\section{Considerações Finais}

Deste modo, podemos dizer que a cultura da mídia está entranhada nas práticas sociais e coletivas. Já não temos mais como separá-las ou como definir o homem sem passar por sua relação com os meios de comunicação, em especial com as imagens. De um lado, porque as imagens o cercam, de outro, porque ele as cerca e as produz, incessantemente, numa forma de produzir a realidade. As lógicas midiáticas, portanto, estão atreladas ao nosso cotidiano e permitem níveis cada vez mais complexos de usos e de apropriações, conforme as possibilidades de acesso às tecnologias, aos dispositivos sóciosemio-técnicos, mas, especialmente, ao grau de experiência com estes dispositivos. Isto é: estamos num cenário de crescente midiatização, um fenômeno em curso, mas já bastante solidificado em termos de circulação.

Na visada deste texto, a circulação é compreendida como o espaço, 0 entre-lugar, em que ocorre a atribuição de valor, portanto onde o sentido de fato se forma, em disputa entre instituições midiáticas jornalísticas e atores sociais midiatizados. Embora não haja equilíbrio em termos de tempos e espaços, ambos possuem condições de atribuir valor às imagens para que possam ser inseridas, reinseridas, reelaboradas, preenchidas de novos sentidos. Tais movimentos são evidenciados em cinco níveis, mas apenas dois são, de fato, discutidos ao longo deste trabalho: as fagias. A primeira diz respeito ao desejo de se alimentar de imagens preservando o sentido original das primeiras "aparições", ainda que novos textos, legendas e interpretações sejam acrescidos por atores sociais em seus dispositivos. Já a segunda, a fagia midiática, refere-se à fome da própria mídia em consumir aquilo que foi regurgitado pelos atores sociais. Para isso, são acrescidas novas camadas de sentido, adaptadas conforme as regras tácitas do jornalismo e dos veículos a que se destinam.

0 caso abordado, a imagem de Aylan Kurdi, demonstra não apenas os dois tipos de fagia, mas 0 êxito do programa da gula adaptado da proposição de Flusser (2006). A gula é entendida, aqui, como uma atividade criadora da realidade, pois sem a devoração, sem a transformação em símbolo não há realidade. Portanto, vivemos na ambiência do não-existente, da mera imagem, uma vez que a materialidade do fato importa pouco. Este fato, para existir, precisa ser transformado, integrado. Neste sentido, entendemos que a imagem de Aylan Kurdi passa pelas etapas da devoração, do engolimento, mas não da digestão, necessariamente, pois digerir implica compreender em profundidade, o que na fagia social e na fagia midiática não encontra pleno espaço em virtude da produção acelerada de novos circuitos. Em contrapartida, observa-se que ocorre o expelir da imagem, ou seja, a sua transformação em novos instrumentos, em uma materialidade que já não é mais o fato em si.

0 acessível agora não é mais o fato do corpo encontrado em uma praia em um dia de setembro, 
mas o da imagem cristalizada. Esta é tão forte que passa a ter um potencial simbólico, uma vez que não apenas traduz um acontecimento, mas se constitui nele. Para isso, entram em jogo lógicas midiáticas que envolvem o fazer de instituições, midiáticas ou não, e dos atores sociais e de como tais esferas lidaram com a oferta, 0 aparecimento, o apagamento, a replicação, a restrição e a totemização de tal imagem ou de outras referentes ao caso. Apesar das tentativas de quebra, a imagem de Aylan Kurdi é dominante perante outras, pois possui poder estruturante de interações, ao mesmo tempo em que revela um poder transcendente, um poder social que se manifesta. A imagem-totem é, então, de um lado, fruto de um poder simbólico manifesto e, de outro, autorreferencial, isto é, o próprio objeto representado, uma vez que a imagem amplamente reiterada adere ao que representa, substituindo 0 próprio fato. Desta forma, a imagem-totem é resultado da restrição da interpretação, ou seja, as imagens se tornam mais do que metáforas visuais, sobrevivem para além do acontecimento, substituindo o referente, por sua reiteração e fixação, adquirindo um status de sagrado.

\section{Referências bibliográficas}

BAITELLO JR, Norval. A era da iconofagia: ensaios de comunicação e cultura. São Paulo: Hacker Editores, 2005.

BELTING, Hans. Pour une anthropologie des images. Paris: Gallimard, 2004.

BRAGA, Jose Luiz. "Circuitos versus Campus". In: JANOTTI JR, J; MATTOS, M A; JACKS, N. Mediação \&
Midiatização. Salvador: EDUFBA, Brasília COMPOS, 2012. p.31-52.

BRAGA, Jose Luiz; FERREIRA, Jairo; FAUSTO NETO, Antonio.; GOMES, Pedro Gilberto. (orgs). Dez Perguntas para a produção de conhecimento em comunicação. São Leopoldo: Unisinos, 2013.

CALVINO, Ítalo. Seis propostas para o próximo milênio: lições americanas. $2^{\mathrm{a}}$ edição. São Paulo: Companhia das Letras, 1998.

CASSIRER, Ernst. A filosofia das formas simbólicas. Vol II - 0 pensamento mítico. São Paulo: Martins Fontes, 2004.

\section{Ensaio sobre o Homem:}

introdução a uma filosofia da cultura humana. Martins Fontes: São Paulo, 1994.

DURAND, Gilbert. 0 imaginário: ensaio acerca das ciências da filosofia e da imagem. Rio de Janeiro: Diefel, 2004.

FAUSTO NETO, A. "Fragmentos de uma analítica da midiatização". In: Revista Matrizes. N02, abril, 2008. Disponível em http://200.144.189.42/ojs/index. php/MATRIZes/article/viewArticle/5236 (acesso em 17/07/2015)

FERREIRA, Jairo. "Notícia sobre as Ongs: uma conjuntura aberta pelos dispositivos midiáticos na web". In: FERREIRA, Jairo; VIZER, Eduardo (orgs). Mídia e movimentos sociais: linguagens e coletivos em ação. São Paulo: Paulus, 2007. p.133-148.

FERREIRA, Jairo; ROSA. Ana Paula da. "Midiatização e poder". In: TEMER, Ana (org). Mídia Cidadania e Poder. Goiânia: FACOMB/ FUNAPE, 2011. p.19-38 FLUSSER, Vilem. A história do diabo. São Paulo: Annablume, 2006.

GOMES, Pedro Gilberto. Como o processo de midiatização (um novo modo de ser no mundo) afeta as relações sociais: In: BRAGA, Jose Luiz; FERREIRA, Jairo; FAUSTO NETO, Antonio.; GOMES, Pedro 
Gilberto. (orgs). Dez Perguntas para a produção de conhecimento em comunicação. São Leopoldo: Unisinos, 2013.

KAMPER, Dietmar. "Imagem". In: Cosmo, Corpo, Cultura: Enciclopédia Antropológica. A cura de Christoph Wulf. Milano, Itália: Ed. Mondadori, 2002. Disponível em http://www.cisc.org.br/portal/index. php/pt/biblioteca/viewdownload/3-kamper-dietmar/15imagem.html (acesso em 12/10/2015)

PEIRCE, Charles Sanders. Semiótica. São Paulo: Editora Perspectiva, 2003.

ROSA, Ana Paula da. De reflexos a fagias: os níveis de circulação e apropriação midiática das imagens. Paper apresentado no Colóquio Internacional de Midiatização (CIM). Argentina, 2015. (prelo) . Atentado em looping: uma palavra que aciona uma imagem. In: Revista Famecos. Vol 22, $n^{0} 04,2015$. Disponível em http://revistaseletronicas.pucrs.br/ojs/index.php/ revistafamecos/article/view/20992 Acesso em 20/08/2015. . Imagens-totens em permanência $x$ tentativas midiáticas de ruptura. In: ARAUJO, Denize; CONTRERA, Malena (orgs).Teorias do Imaginário. Compós, Brasília, 2014. p. 28-50 Disponível em http://www.compos.org.br/data/teorias_ da_imagem_e_do_imaginario.pdf

VERON, Eliseo. La semiosis social 2: ideas, momentos, interpretantes. Buenos Aires:Paidós, 2013. . Teoria da midiatização: uma perspectiva semioantropológica e algumas de suas consequências. In: Revista Matrizes. Vol. 08, nº 01, 2014. . A produção do sentido. São Paulo:

Cultrix, 1980.

\section{Sites consultados}

A IMAGEM de Aylan Kurdi despertou o mundo para esta crise. Facebook Aylan Kurdi Caravan. Portugal, setembro de 2015. https:/www.facebook.com/

AylanKurdiCaravan (acesso em 20/01/2016)

"AT THAT moment, when I saw the 3 year-old Aylan Kurdi, I was petrified", photographer Nilufer Demir. Sri Lanka Brief. Sri Lanka, 05 de setembro de 2015. Disponível em http://srilankabrief.org/2015/09/atthat-moment-when-i-saw-the-3-year-old-aylan-kurdi-iwas-petrified-photographer-nilufer-demir/ (acesso em 20/01/2016)

COLON, Leandro. Foto de menino refugiado morto na praia atrai atenção para crise. Folha de S. Paulo. São Paulo, 3 de setembro de 2015. Disponível em http:// www1.folha.uol.com.br/mundo/2015/09/1677028-fotode-menino-refugiado-morto-na-praia-atrai-at ELGLOT, Jessica. Family of Syrian boy washed up on beach were trying to reach Canada. The Guardian. Londres, 03 de setembro de 2015. Disponível em https://www. theguardian.com/world/2015/sep/03/refugee-crisissyrian-boy-washed-up-on-beach-turkey-trying-to-reachcanada (acesso em 09/09/2015)

EVANGELISTA, Francisco. Onde estava Deus quando Aylan Kurdi morreu afogado no mar da Turquia? Blog Francisco Evangelista. 08 de setembro de 2015. Disponível em: http://www.franciscoevangelista. com/2015/09/onde-estava-deus-quando-aylan-kurdi. html (acesso em 10/09/2015)

GAR0T0 sírio se torna o rosto do drama dos refugiados. Zero Hora. Porto Alegre, 03 de setembro de 2015. Disponível em http://zh.clicrbs.com.br/rs/ noticias/noticia/2015/09/garoto-sirio-se-torna-o-rostodo-drama-dos-refugiados-4840311.html (acesso em $10 / 09 / 2015)$

GUILLEN, David Sanchez. En memoria de Aylan Kurdi. Canal Youtube David Sanchez. 05 de novembro de 2015. Disponível em https://www.youtube.com/ watch?v=SGqs_vlBKUI\&feature $=$ youtube $($ acesso em 20/01/2016)

HEALING, Janice. His name was Aylan... Syrian Boy is symbol of refugee tragedy. EYEWITNESS NEWS. 
Johannesburg, 3 de setembro de 2015. Disponível em

http://ewn.co.za///media/88AF3C434FAD4500B28035E2

684167FF.ashx (acesso em 20/01/2016)

ILUSTRAÇÕES na internet homenageiam menino sírio morto em praia. Portal G1. São Paulo, 03 de setembro de 2015. Disponível em http://g1.globo.com/mundo/ noticia/2015/09/ilustracoes-homenageiam-meninosirio-morto-em-praia-em-redes-sociais.html (acesso em 06/09/2015)

IMAGEM retrata 'grito de um corpo silencioso', diz autora de foto do menino sírio. Revista Veja. São Paulo, 3 de setembro de 2015. Disponível em http:// veja.abril.com.br/noticia/mundo/imagem-retrata-gritode-um-corpo-silencioso-diz-autora-de-foto-do-meninosirio/ (acesso em 06/09/2015)

RODRIGUES, Dario. Minha imagem do ano de 2015. Aylan Kurdi: tragédia, guerra, vida e morte. Blog Dario Benedito Rodrigues. 29 de dezembro de 2015. Disponível em: http://profdariobenedito.blogspot.com. br/2015/12/minha-imagem-do-ano-de-2015-aylankurdi_29.html (acesso em 20/01/2017)

SMITH, Helena. Shocking images of drowned Syrian boy show tragic plight of refugees. The Guardian. Londres, 02 de setembro de 2015. Disponível em: http://www. theguardian.com/world/2015/sep/02/shocking-imageof-drowned-syrian-boy-shows-tragic-plight-of-refugees (acesso em 09/09/2015) 


\section{The success of gluttony: totem image indestructibility in Aylan Kurdi's case}

\section{Abstract}

In a scenario marked by mediatization, the culture is crossed by communication logics that are evident in the media devices. Such context is the background of this article that aims to discuss the circulation of the image of Aylan Kurdi, found dead on a beach in September 2015. From the hypothesis of five movements of circulation (ROSA, 2016), we question: in what extent do the social and mediatic phagias, perceptible by the consumption and replication of photographs, allow to mobilize the program of gluttony created by Flusser? In order to answer this question, we developed the empirical analysis of the case, besides the conceptual tension of iconophagia (BAITELLO JR, 2005), gluttony (FLUSSER, 2006), in addition to the contributions of mediatization.

\section{Keywords}

Image. Circulation. Mediatization.

\section{El éxito de la gula:}

\section{la indestructibilidad de la} imagen tótem de Aylan Kurdi

\section{Resumen}

En un escenario marcado por la mediatización, la cultura es atravesada por lógicas comunicacionales que se evidencian en los dispositivos mediáticos. Este contexto es el telón de fondo de este artículo que trata de discutir la circulación de la imagen de Aylan Kurdi, encontrado muerto en una playa en septiembre de 2015. A partir de la hipótesis de cinco movimientos de circulación (ROSA, 2016), se pregunta: ¿Qué medida las fagias social y mediática, perceptibles por el consumo y replicación de fotografías, permiten movilizar el programa de la gula, creado por Flusser? Para responder a esta cuestión desarrollamos el análisis empírico del caso, además del tensionamiento conceptual de iconofagia (BAITELLO JR, 2005), de gula (FLUSSER, 2006), además de los aportes de la mediatización.

\section{Palabras clave}

Imagen. Circulación. Mediatización. 


\section{Expediente}

A revista E-Compós é a publicação científica em formato eletrônico da Associação Nacional dos Programas de Pós-Graduação em Comunicação (Compós). Lançada em 2004, tem como principal finalidade difundir a produção acadêmica de pesquisadores da área de Comunicação, inseridos em instituições do Brasil e do exterior.

\section{E-COMPÓS I www.e-compos.org.br I E-ISSN 1808-2599}

Revista da Associação Nacional dos Programas de Pós-Graduação em Comunicação.

Brasília, v.20, n.2, maio/ago. 2017.

A identificação das edições, a partir de 2008, passa a ser volume anual com três números.

Indexada por Latindex I www.latindex.unam.mx

\section{CONSELHO EDITORIAL}

Alda Cristina Silva da Costa, Universidade Federal do Pará, Brasil Alfredo Luiz Paes de Oliveira Suppia, Universidade Estadual de Campinas, Brasil Álvaro Larangeira, Universidade Tuiuti do Paraná, Brasil Ana Carolina D. Escosteguy, Pontifícia Universidade Católica do Rio Grande do Sul, Brasil Ana Regina Barros Rego Leal, Universidade Federal do Piauí, Brasil Ana Carolina Rocha Pessôa Temer, Universidade Federal de Goiás, Brasil Andrea França, Pontifícia Universidade Católica do Rio de Janeiro, Brasil André Luiz Martins Lemos, Universidade Federal da Bahia, Brasil Angela Cristina Salgueiro Marques, Faculdade Cásper Líbero, Brasil Ângela Freire Prysthon, Universidade Federal de Pernambuco, Brasil Antonio Carlos Hohlfeldt, Pontifícia Universidade Católica do Rio Grande do Sul, Brasil Arthur Ituassu, Pontifícia Universidade Católica do Rio de Janeiro, Brasil Bruno Campanella, Universidade Federal Fluminense, Brasil Cláudio Novaes Pinto Coelho, Faculdade Cásper Líbero, Brasil Carlos Eduardo Franciscato, Universidade Federal de Sergipe, Brasil Denise Tavares da Silva, Universidade Federal Fluminense, Brasil Eduardo Vicente, Universidade de São Paulo, Brasil Eliza Bachega Casadei, Escola Superior de Propaganda e Marketing - SP, Brasil Elizabeth Nicolau Saad Corrêa, Universidade de São Paulo, Brasil Erick Felinto de Oliveira, Universidade do Estado do Rio de Janeiro, Brasil Erly Vieira Júnior, Universidade Federal do Espírito Santo, Brasil Francisco de Assis, FIAM-FAAM Centro Universitário, Brasil Francisco Elinaldo Teixeira, Universidade Estadual de Campinas, Brasil Frederico de Mello Brandão Tavares, Universidade Federal de Ouro Preto, Brasil Gabriela Reinaldo, Universidade Federal do Ceará, Brasil

Gilson Vieira Monteiro, Universidade Federal do Amazonas, Brasil Gustavo Daudt Fischer, Universidade do Vale do Rio dos Sinos, Brasi Itania Maria Mota Gomes, Universidade Federal da Bahia, Brasil Jiani Adriana Bonin, Universidade do Vale do Rio dos Sinos, Brasil José Afonso da Silva Junior, Universidade Federal de Pernambuco, Brasil José Luiz Aidar Prado, Pontifícia Universidade Católica de São Paulo, Brasi
Juçara Gorski Brittes, Universidade Federal de Ouro Preto, Brasil Juliana Freire Gutmann, Universidade Federal da Bahia, Brasil Laura Loguercio Cánepa, Universidade Anhembi Morumbi, Brasil Letícia Cantarela Matheus, Universidade do Estado do Rio de Janeiro, Brasil Liziane Soares Guazina, Universidade de Brasilia, Brasil Luíza Mônica Assis da Silva, Universidade Católica de Brasília, Brasil Maria Ataide Malcher, Universidade Federal do Pará, Brasil Maria Elisabete Antonioli, Escola Superior de Propaganda e Marketing - SP, Brasil Maria das Graças Pinto Coelho, Universidade Federal do Rio Grande do Norte, Brasil Marcel Vieira Barreto Silva, Universidade Federal da Paraíba, Brasil Marcia Tondato, Escola Superior de Propaganda e Marketing, Brasil Marli Santos, Universidade Metodista de São Paulo, Brasil Márcio Souza Gonçalves, Universidade do Estado do Rio de Janeiro, Brasil Mauricio Mario Monteiro, Universidade Anhembi Morumbi, Brasil Mauricio Ribeiro da Silva, Universidade Paulista, Brasil Mauro de Souza Ventura, Universidade Estadual Paulista, Brasil Mayka Castellano, Universidade Federal Fluminense, Brasi Micael Maiolino Herschmann, Universidade Federal do Rio de Janeiro, Brasil Mozahir Salomão Bruck, Pontifícia Universidade Católica de Minas Gerais, Brasil Nísia Martins Rosario, Universidade Federal do Rio Grande do Sul, Brasil Potiguara Mendes Silveira Jr, Universidade Federal de Juiz de Fora, Brasil Rafael Grohmann, FIAM-FAAM - Centro Universitário, Brasil Raquel Ritter Longhi, Universidade Federal de Santa Catarina, Brasil Regiane Regina Ribeiro, Universidade Federal do Paraná, Brasil Roberto Elísio dos Santos, Universidade Municipal de São Caetano do Sul, Brasil Rodolfo Rorato Londero, Universidade Estadual de Londrina, Brasil Sérgio Luiz Gadini, Universidade Estadual de Ponta Grossa, Brasil Simone Maria Andrade Pereira de Sá, Universidade Federal Fluminense, Brasil Simone Maria Rocha, Universidade Federal de Minas Gerais, Brasil Suzana Reck Miranda, Universidade Federal de São Carlos, Brasil Tarcyanie Cajueiro Santos, Universidade de Sorocaba, Brasil

Tatiana Oliveira Siciliano, Pontifícia Universidade Católica do Rio de Janeiro, Brasil Veneza Mayora Ronsini, Universidade Federal de Santa Maria, Brasil

\section{CONSELHO CIENTÍFICO}

Cristiane Freitas Gutfreind, Pontifícia Universidade Católica do Rio Grande do Sul, Brasil | Eduardo Antônio de Jesus, Universidade Federal de Minhas Gerais, Brasil | Eduardo Morettin, Universidade de São Paulo, Brasil I Irene de Araújo Machado, Universidade de São Paulo, Brasil I Miriam de Souza Rossini, Universidade Federal do Rio Grande do Sul, Brasil

\section{COMISSÃO EDITORIAL}

Eduardo Antonio de Jesus, Universidade Federal de Minas Gerais, Brasil I Igor Pinto Sacramento, Universidade Federal do Rio de Janeiro, Brasil I Kelly Cristina de Souza Prudencio, Universidade Federal do Paraná, Brasil I Osmar Gonçalves dos Reis Filho, Universidade Federal do Ceará, Brasil

\section{CONSULTORES AD HOC}

Cesar Augusto Baio Santos, Universidade Federal do Ceará, Brasil I Lilian França, Universidade Federal de Sergipe, Brasil I Maria Aparecida Baccega, Escola Superior de Propaganda e Marketing, Brasil I Márcia Benetti, Universidade Federal do Rio Grande do Sul, Brasil I Miguel Serpa Pereira, Pontifícia Universidade Católica do Rio de Janeiro, Brasil | Renato Essenfelder, Escola Superior de Propaganda e Marketing, Brasil

\section{EQUIPE TÉCNICA}

ASSISTENTE EDITORIAL Márcio Zanetti Negrini I REVISÃO DE TEXTOS Melina Santos | EDITORAÇÃ̃ ELETRÔNICA Roka Estúdio I IMAGEM DE CAPA Silas de Paula

\section{COMPÓS I www.compos.org.br}

Associação Nacional dos Programas de Pós-Graduação em Comunicação

Presidente

Marco Roxo

Programa de Pós-Graduação em Comunicação - UFF marcos-roxo@uol.com.br

Vice-Presidente

Isaltina Gomes

Programa de Pós-Graduação em Comunicação - UFPE

isaltina@gmail.com

Secretária-Geral

Gisela Castro

Programa de Pós-Graduação em Comunicação

e Práticas de Consumo - ESPM

castro.gisela@gmail.com

CONTATO I revistaecompos@gmail.com 